Article

\title{
The Interplay between Various $\sigma$ - and $\pi$-Hole Interactions of Trigonal Boron and Trigonal Pyramidal Arsenic Triiodides
}

\author{
Jindřich Fanfrlík ${ }^{1,+}{ }^{,}$Petr Švec ${ }^{2, \dagger}{ }^{,}$Zdeňka Růžičková ${ }^{2}$, Drahomír Hnyk ${ }^{3}$, Aleš Růžička ${ }^{2, *}$ and \\ Pavel Hobza 1,4,* \\ 1 Institute of Organic Chemistry and Biochemistry of the Czech Academy of Sciences, Flemingovo nam. 2, \\ 16610 Prague 6, Czech Republic; fanfrlik@uochb.cas.cz \\ 2 Department of General and Inorganic Chemistry, Faculty of Chemical Technology, University of Pardubice, \\ Studentská 573, 53210 Pardubice, Czech Republic; Petr.Svec2@upce.cz (P.Š.); \\ Zdenka.Ruzickova@upce.cz (Z.R.) \\ 3 Institute of Inorganic Chemistry of the Czech Academy of Sciences,

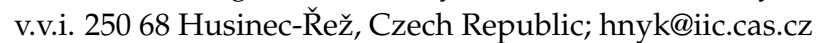 \\ 4 Regional Centre of Advanced Technologies and Materials, Department of Physical Chemistry, \\ Palacký University, 77146 Olomouc, Czech Republic \\ * Correspondence: ales.ruzicka@upce.cz (A.R.); hobza@uochb.cas.cz (P.H.) \\ $\dagger$ These authors contributed equally to this work.
}

Academic Editors: Peter Politzer and Jane S. Murray

Received: 26 June 2017; Accepted: 17 July 2017; Published: 19 July 2017

\begin{abstract}
Boron and arsenic triiodides $\left(\mathrm{BI}_{3}\right.$ and $\mathrm{AsI}_{3}$, respectively) are similar molecules that differ mainly in their geometries. $\mathrm{BI}_{3}$ is a planar trigonal molecule with $D_{3 \mathrm{~h}}$ symmetry, while AsI $\mathrm{A}_{3}$ exhibits a trigonal pyramidal shape with $C_{3 \mathrm{v}}$ symmetry. Consequently, the As atom of the $\mathrm{AsI}_{3}$ molecule has three $\sigma$-holes, whereas the $\mathrm{B}$ atom of the $\mathrm{BI}_{3}$ molecule has two symmetrical $\pi$-holes. Additionally, there are $\sigma$-holes on the iodine atoms in the molecules studied. In the first step, we have studied $\sigma$-hole and $\pi$-hole interactions in the known monocrystals of $\mathrm{BI}_{3}$ and $\mathrm{AsI}_{3}$. Quantum mechanical calculations have revealed that the crystal packing of $\mathrm{BI}_{3}$ is dominated by $\pi$-hole interactions. In the case of $\mathrm{AsI}_{3}$, the overall contribution of dihalogen bonding is comparable to that of pnictogen bonding. Additionally, we have prepared the $\left[\mathrm{Na}(\mathrm{THF})_{6}\right]^{+}\left[\mathrm{I}\left(\mathrm{AsI}_{3}\right)_{6}\right]^{-}\left(\mathrm{AsI}_{3}\right)_{2}$ complex, which can be described as the inverse coordination compound where the iodine anion is the center of the aggregate surrounded by six $\mathrm{AsI}_{3}$ molecules in the close octahedral environment and adjacent two molecules in remote distances. This complex is, besides expected dihalogen and pnictogen bonds, also stabilized by systematically attractive dispersion interactions.
\end{abstract}

Keywords: dihalogen bond; pnictogen bond; pi-back donation; dispersion; inverse coordination

\section{Introduction}

The $\sigma$-hole and $\pi$-hole are regions with a positive electrostatic potential (ESP) surface along the extension of a covalent $\sigma$-bond and in the direction perpendicular to the $\sigma$-bond framework, respectively. These areas with a positive ESP surface enable a counterintuitive noncovalent interaction, at which a partially negatively charged atom interacts with an electron-rich region [1,2]. The best known and most extensively studied is the $\sigma$-hole on halogen $(X)$ atoms, where the respective interactions are called X-bonds [3]. This concept has been extended to chalcogens, pnictogens (Pn), and tetrels [4]. The respective interactions are then called chalcogen-, Pn-, and tetrel-bonds. The $\sigma$-hole can be characterized by its size and magnitude $\left(\mathrm{V}_{\max }\right) . \mathrm{V}_{\max }$ is defined as the value of the most positive ESP of an electron density surface. The more positive the $V_{\max }$, the stronger the respective interaction [5]. 
The properties of $\sigma$-holes can be modulated by changing the chemical environment in order to tune the interactions, e.g., by introducing electron-withdrawing groups in the vicinity of the atom possessing a $\sigma$-hole or a $\pi$-hole. This has already been demonstrated in model systems [6] as well as in protein-ligand complexes $[7,8]$. In contrast to our previous studies, we have compared two very similar molecules here. Specifically, we have opted for $\mathrm{BI}_{3}$ and $\mathrm{AsI}_{3}$. Boron and arsenic have nearly the same value of Pauling electronegativity (2.04 and 2.05, respectively). The major difference between these two molecules thus consists in their geometries. While $\mathrm{BI}_{3}$ is a planar trigonal molecule with $D_{3 \mathrm{~h}}$ symmetry ( $\pi$-back donation is possible here but not in $\mathrm{AsI}_{3}$ ), $\mathrm{AsI}_{3}$ exhibits a trigonal pyramidal shape with $C_{3 \mathrm{v}}$ symmetry with the lone electron pair being pointed to the fourth vertex of virtual $\Psi$-tetrahedron. Firstly, we analyzed single crystalline material, which had already been described in the literature $[9,10]$. Secondly, we reported and analyzed much larger system containing $\left[\mathrm{I}\left(\mathrm{AsI}_{3}\right)_{6}\right]^{-}$ units within $\left[\mathrm{Na}(\mathrm{THF})_{6}\right]^{+}\left[\mathrm{I}\left(\mathrm{AsI}_{3}\right)_{6}\right]^{-}\left(\mathrm{AsI}_{3}\right)_{2}$ complex. In interactions of such large molecular entities, other types of noncovalent interactions like the dispersion ones also play an important role besides the already mentioned $\sigma$-hole interactions. Benchmark interaction energy $(\Delta \mathrm{E})$ values of the binding motifs within the studied crystals were obtained using highly accurate coupled cluster with single, double and perturbative triple excitations $\operatorname{CCSD}(\mathrm{T})$ calculations.

\section{Methods}

\subsection{Experimental}

The preparation and isolation of $\left[\mathrm{Na}(\mathrm{THF})_{6}\right]^{+}\left[\mathrm{I}\left(\mathrm{AsI}_{3}\right)_{6}\right]^{-}\left(\mathrm{AsI}_{3}\right)_{2}$ : Perylene $(207 \mathrm{mg}, 0.82 \mathrm{mmol})$ and $\mathrm{AsI}_{3}(748 \mathrm{mg}, 1.64 \mathrm{mmol})$ were mixed in a THF $/ \mathrm{CH}_{2} \mathrm{Cl}_{2}$ mixture of solvents $(10 \mathrm{~mL}, 1: 1 \mathrm{v} / \mathrm{v})$. The deep orange turbid reaction mixture was stirred overnight and filtered. The clear orange filtrate was stored in a common Schlenk tube in a freezing box for several months. A deep orange precipitate formed very slowly during that period of time. The reaction mixture was filtered one more time to provide a clear orange filtrate, which was stored for several more months at $-40^{\circ} \mathrm{C}$ to provide orange single crystals of the title compound in low yield. Melting point: $140-141^{\circ} \mathrm{C}$.

A clear intense orange block-like specimen of $\mathrm{C}_{24} \mathrm{H}_{48} \mathrm{As}_{8} \mathrm{I}_{25} \mathrm{NaO}_{6}$, approximate dimensions $0.251 \mathrm{~mm} \times 0.260 \mathrm{~mm} \times 0.311 \mathrm{~mm}$, was used for the X-ray crystallographic analysis. The X-ray intensity data were measured. A total of 592 frames were collected. The total exposure time was $0.62 \mathrm{~h}$. The frames were integrated with the Bruker SAINT software package using a narrow-frame algorithm. The integration of the data using a trigonal unit cell yielded a total of 27971 reflections to a maximum $\theta$ angle of $28.32^{\circ}(0.75 \AA$ resolution), of which 3416 were independent (average redundancy 8.188, completeness $\left.=99.8 \%, R_{\text {int }}=5.13 \%, R_{\text {sig }}=2.85 \%\right)$ and $3165(92.65 \%)$ were greater than $2 \sigma\left(F^{2}\right)$. The final cell constants of $a=16.5457(7) \AA, b=16.5457(7) \AA, c=26.0339(11) \AA$, volume $=6172.2(6) \AA^{3}$, are based upon the refinement of the XYZ-centroids of 9856 reflections above $20 \sigma(\mathrm{I})$ with $4.923^{\circ}<2 \theta<56.58^{\circ}$. Data were corrected for absorption effects using the Numerical Mu Calculated method (SADABS). The ratio of minimum to maximum apparent transmission was 0.118 . The calculated minimum and maximum transmission coefficients (based on crystal size) are 0.1110 and 0.1440 .

The structure was solved and refined using the Bruker SHELXTL Software Package (Bruker AXS Inc., Madison, WI, USA), using the space group R-3, with $\mathrm{Z}=3$ for the formula unit, $\mathrm{C}_{24} \mathrm{H}_{48} \mathrm{As}_{8} \mathrm{I}_{25} \mathrm{NaO}_{6}$. The final anisotropic full-matrix least-squares refinement on $\mathrm{F}^{2}$ with 99 variables converged at $R_{1}=2.14 \%$, for the observed data and $w R_{2}=6.19 \%$ for all data. The goodness-of-fit was 1.024 . The largest peak in the final difference electron density synthesis was $1.010 \mathrm{e}^{-} / \AA^{3}$ and the largest hole was $-0.866 \mathrm{e}^{-} / \AA^{3}$ with an RMS deviation of $0.188 \mathrm{e}^{-} / \AA^{3}$. On the basis of the final model, the calculated density was $3.412 \mathrm{~g} / \mathrm{cm}^{3}$ and $\mathrm{F}(000), 5520 \mathrm{e}^{-}$.

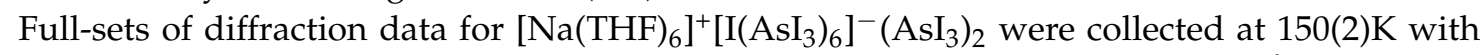
a Bruker D8-Venture diffractometer equipped with $\mathrm{Mo}\left(\mathrm{Mo} / \mathrm{K}_{\lambda}\right.$ radiation; $\lambda=0.71073 \AA$ ) microfocus X-ray $(\mathrm{I} \mu \mathrm{S})$ source, Photon CMOS detector (Bruker AXS Inc., Madison, WI, USA) and Oxford 
Cryostream 800 Series cooling device (Oxford Cryosystems Ltd., Oxford, UK) was used for data collection.

The frames were integrated with the Bruker SAINT software package (Bruker AXS Inc., Madison, WI, USA) using a narrow-frame algorithm. Data were corrected for absorption effects using the Multi-Scan method (SADABS). Obtained data were treated by XT-version 2014/5 (Bruker AXS Inc., Madison, WI, USA) and SHELXL-2014/7 software implemented in APEX3 v2016.5-0 (Bruker AXS) system [11].

Hydrogen atoms were mostly localized on a difference Fourier map, however to ensure uniformity of treatment of crystal, all hydrogen was recalculated into idealized positions (riding model) and assigned temperature factors $\mathrm{H}_{\text {iso }}(\mathrm{H})=1.2 \mathrm{U}_{\text {eq }}$ (pivot atom). $\mathrm{H}$ atoms in methylene groups was 0.97 .

Crystallographic data for structural analysis have been deposited with the Cambridge Crystallographic Data Centre, CCDC no. 1555393. Copies of this information may be obtained free of charge from The Director, CCDC, 12 Union Road, Cambridge CB2 1EY, UK (fax: +44-1223-336033; e-mail: deposit@ccdc.cam.ac.uk or www: http://www.ccdc.cam.ac.uk).

\subsection{Computations}

Electrostatic potentials were computed by Hartree-Fock (HF) method with the correlation consistent-polarized valence double zeta (cc-pVDZ) basis set (for I, the double zeta polarized (DZP) basis set and a pseudopotential were used) [12] using the Gaussian09 [13] and Molekel4.3 [14,15] programs. It has recently been shown that such a basis set size is sufficient for these purposes [16].

$\Delta \mathrm{E}$ values were calculated at the $\operatorname{CCSD}(\mathrm{T})$ level of theory using the Turbomole 6.6 [17] and Cuby4 [18] programs. CCSD(T) with complete basis set (CBS) was calculated as the sum of the Møller-Plesset perturbation theory to second order (MP2) CBS energy and CCSD(T) correction. MP2 energy was extrapolated to the CBS from correlation consistent-polarized triple zeta (cc-pVTZ) to correlation consistent-polarized valence quadruple zeta cc-pVQZ (for I atoms, cc-pVTZ-PP and cc-pVQZ-PP with pseudopotentials (PP) were used) [19]. The CCSD(T) correction term was calculated using the aug-cc-pVDZ basis set (aug-cc-pVDZ-PP for I). Counterpoise corrections for the basis set superposition error (BSSE) and the resolution of identity (RI) approximation were used.

\section{Results and Discussion}

In the first step, the computed properties of isolated $\mathrm{BI}_{3}$ and $\mathrm{AsI}_{3}$ molecules were compared (see Table 1 and Figure 1). The iodine atoms of both $\mathrm{BI}_{3}$ and $\mathrm{AsI}_{3}$ have $\sigma$-holes with comparable $\mathrm{V}_{\mathrm{s}, \max }$ values of about 22.3 and $23.2 \mathrm{kcal} \cdot \mathrm{mol}^{-1}$, respectively, which make them good X-bond donors. Due to the partially negative belt around the center of the $X$ atoms, they can also act as electron donors. The belt of iodine atoms is slightly more negative in the case of the $\mathrm{AsI}_{3}$ molecule (the $\mathrm{V}_{\text {min }}$ values of $\mathrm{BI}_{3}$ and $\mathrm{AsI}_{3}$ are -6.0 and $-7.5 \mathrm{kcal} \cdot \mathrm{mol}^{-1}$, respectively; see also Figure 1). Bigger differences can be found when comparing the ESP on central $\mathrm{B}$ and As atoms. Whereas the As atom of the $\mathrm{AsI}_{3}$ molecule has three $\sigma$-holes, the $\mathrm{B}$ atom of the $\mathrm{BI}_{3}$ molecule has two symmetrical $\pi$-holes. Both the $\mathrm{B}$ and As atoms have high $\mathrm{V}_{\max }$ values, slightly higher than the $\sigma$-holes on the iodine atoms. Additionally, the $\mathrm{V}_{\max }$ values of the $\pi$-holes of $\mathrm{BI}_{3}$ with those of $\mathrm{B}\left(\mathrm{CH}_{3}\right)_{3}$ and $\mathrm{B}\left(\mathrm{CH}=\mathrm{CH}_{2}\right)_{3}$ have been compared. While $\mathrm{B}\left(\mathrm{CH}_{3}\right)_{3}$ has a $\pi$-hole with a similar $\mathrm{V}_{\max }$ value of $25.4 \mathrm{kcal} \cdot \mathrm{mol}^{-1}, \mathrm{~B}\left(\mathrm{CH}=\mathrm{CH}_{2}\right)_{3}$ has a considerably lower $\mathrm{V}_{\max }$ value of $10.4 \mathrm{kcal} \cdot \mathrm{mol}^{-1}$ (ESP surfaces not shown). This difference in $\mathrm{V}_{\text {max }}$ values might be explained through $\pi$-back donation from the $\mathrm{C}=\mathrm{C}$ double bond to the vacant $p_{\mathrm{z}}$ orbital on the $\mathrm{B}$ atom. Such a hypothesis has already been used to explain the elongation of the $\mathrm{C}=\mathrm{C}$ bond in the electron-diffraction structure of $\mathrm{B}\left(\mathrm{CH}=\mathrm{CH}_{2}\right)_{3}$ [20]. In the case of $\mathrm{B}\left(\mathrm{NHCH}_{3}\right)_{3}$ [21], the $\pi$-hole vanishes completely and $\mathrm{V}_{\max }$ has a negative value. 
Table 1. The electrostatic potential surface maxima $\left(V_{\max }\right)$ in $\mathrm{kcal} \cdot \mathrm{mol}^{-1}$. Dipole moments $(\mu)$ in D.

\begin{tabular}{cccc}
\hline Molecule & Atom & $\mathbf{V}_{\text {max }}$ & $\mu$ \\
\hline \multirow{2}{*}{$\mathrm{BI}_{3}$} & $\mathrm{~B}$ & $2 \times 23.5$ & \multirow{2}{*}{0.00} \\
\cline { 2 - 3 } & $\mathrm{I}$ & 22.3 & \\
\hline \multirow{2}{*}{$\mathrm{AsI}_{3}$} & As & $3 \times 25.7$ & \multirow{2}{*}{0.74} \\
\cline { 2 - 3 } & $\mathrm{I}$ & 23.2 & \\
\hline
\end{tabular}

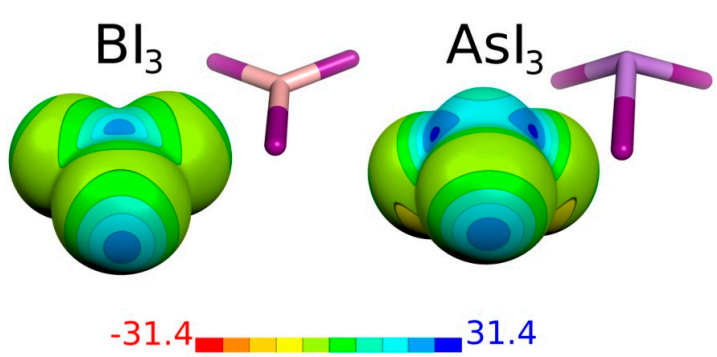

Figure 1. The computed electrostatic potential (ESP) on a 0.001 a.u. molecular surface and molecular diagrams. The color range of the ESP in $\mathrm{kcal} \cdot \mathrm{mol}^{-1}$.

In the next step, the strength of pairwise interactions in the single crystals of $\mathrm{BI}_{3}$ and $\mathrm{AsI}_{3}$ molecules was analyzed by means of quantum chemistry (Table 2). The structure in single crystalline $\mathrm{BI}_{3}$ is mainly stabilized by interactions between the positive $\pi$-holes on the $\mathrm{B}$ atom and the negative belt on iodine atoms, i.e., a parallel displaced motif (see Figure $2 a$ ). The A $\cdots B$ binding motif has two symmetrical interactions of the $\pi$-holes with the negative belt of I atoms (the B $\cdots I$ distance of $4.4 \AA$, the I-B $\cdots \mathrm{I}$ angle of $71.1^{\circ}$, the $\mathrm{B} \cdots \mathrm{I}-\mathrm{B}$ angle of $108.8^{\circ}$ and the $\Delta \mathrm{E}$ of $\left.-6.13 \mathrm{kcal} \cdot \mathrm{mol}^{-1}\right) . \mathrm{BI}_{3}$ also forms

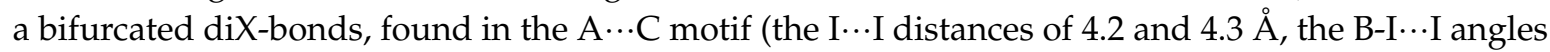
of $156.3^{\circ}$ and $153.1^{\circ}$, and the I $\cdots$ I-B angles of 96.4 and $93.1^{\circ}$ ), which are, however, weaker in this case, with the $\Delta \mathrm{E}$ of $-2.78 \mathrm{kcal} \cdot \mathrm{mol}^{-1}$.

Table 2. Interaction energies in $\mathrm{kcal} \cdot \mathrm{mol}^{-1}$.

\begin{tabular}{cccc}
\hline Crystal & Motif & Interaction & CCSD(T)/CBS \\
\hline \multirow{2}{*}{$\mathrm{BI}_{3}$} & $\mathrm{~A} \cdots \mathrm{B}$ & $2 \times \pi$-hole bonding & -6.13 \\
\cline { 2 - 5 } & $\mathrm{A} \cdots \mathrm{C}$ & Bifurcated diX-bond & -2.78 \\
\hline \multirow{2}{*}{$\mathrm{AsI}_{3}$} & $\mathrm{~A} \cdots \mathrm{B}$ & $2 \times$ Pn-bonding & -7.52 \\
\cline { 2 - 5 } & $\mathrm{A} \cdots \mathrm{C}$ & $2 \times$ Bifurcated diX-bonding & -4.43 \\
\cline { 2 - 4 } & $\mathrm{A} \cdots \mathrm{D}$ & Bifurcated diX-bonding & -3.26 \\
\hline \multirow{2}{*}[\mathrm{Na}(\mathrm{THF})_{6}]{$^{+}\left[\mathrm{I}\left(\mathrm{AsI}_{3}\right)_{6}\right]^{-}\left(\mathrm{AsI}_{3}\right)_{2}$} & $\mathrm{~A} \cdots \mathrm{I}^{-}$ & Pn-bonding & -23.59 \\
\cline { 2 - 4 } & $\mathrm{A} \cdots \mathrm{B}$ & Pn-bonding & -4.64 \\
\cline { 2 - 4 } & $\mathrm{B} \cdots \mathrm{C}$ & diX-bonding & -2.24 \\
\hline
\end{tabular}

In the case of $\mathrm{AsI}_{3}$, the most negative $\Delta \mathrm{E}$ has also been found for the binding motif where the electron acceptor is the central atom (see Figure $2 \mathrm{~b}$ and Table 2). It is the A-B motif with two symmetrical Pn-bonds (the As $\cdots I$ distance of $3.5 \AA$, the I-As $\cdots I$ angle of $160.7^{\circ}$, the As $\cdots I$-As angle of $91.3^{\circ}$ and the $\Delta \mathrm{E}$ of $-7.52 \mathrm{kcal} \cdot \mathrm{mol}^{-1}$ ). Interestingly, diX-bonds are more numerous in the case of $\mathrm{AsI}_{3}$ (the diX-bonds with the I $\cdots \mathrm{I}$ distances of $4.2-4.3 \AA$, the As-I $\cdots I$ angles of $142^{\circ}-151^{\circ}$ and the I $\cdots$ I-B angles of $92^{\circ}-99^{\circ}$ ) and also stronger (the $\Delta \mathrm{E}$ of -4.43 and $-3.26 \mathrm{kcal} \cdot \mathrm{mol}^{-1}$ for the $\mathrm{A} \cdots \mathrm{C}$ and A ...D motifs, respectively). Consequently, Pn-bonding and diX-bonding have a comparable overall contribution for the crystal packing of $\mathrm{AsI}_{3}$. 
Finally, we report the $\left[\mathrm{Na}(\mathrm{THF})_{6}\right]^{+}\left[\mathrm{I}\left(\mathrm{AsI}_{3}\right)_{6}\right]^{-}\left(\mathrm{AsI}_{3}\right)_{2}$ complex. Crystalline material was prepared accidentally during the attempts to synthesize a complex analogous to the previously published adducts of arenes and $\mathrm{SbCl}_{3}$ [22-24]. The exchange of the sodium cation from the borosilicate Simax ${ }^{\circledR}$ glassware (Kavalierglass, a.s., Sázava, Czech Republic) and the arsenic atom obviously took place (see Figure 3). This is easily acceptable as the arsenic impurities or additives can be found in various types of glasses [25,26]. A high tendency of the sodium atom to migrate from the glass surface and to form ionic compounds and complexes in solution is documented, for instance, by the existence of this phenomenon in glass electrodes and almost eighty examples of the sodium cation coordinated by six THF molecules found in the Cambridge Crystallographic Database. The $\left[\mathrm{Na}(\mathrm{THF})_{6}\right]^{+}\left[\mathrm{I}\left(\mathrm{AsI}_{3}\right)_{6}\right]^{-}\left(\mathrm{AsI}_{3}\right)_{2}$ complex is formed of a sodium cation surrounded by six THF molecules with octahedral geometry and iodide which has six molecules of the arsenic triiodide localized in the 'primary coordination sphere' $\left(\mathrm{d}_{\text {As1-I5 }}\right.$ 3.294(3) $\left.\mathrm{A}\right)$ and adjacent two molecules of arsenic triiodide in the 'second coordination sphere' $\left(\mathrm{d}_{\mathrm{As2} 2 \mathrm{I} 5} 5.738(3) \AA\right)$. From the point of view of the closer analysis, the topology of the underlying net is bcu-x in molecular ion-packing representation [27]. The geometry of the described object based on the locations of the arsenic atoms and the central iodine ion is thus the dual pair of the Platonic solids-the cube and the octahedron, where only two vertexes of the cube are present bi-capping the opposite vertexes of the octahedra (Figure 4). According to the novel inverse coordination concept [28], the title complex could be also described as the inverse coordination compound where the iodine anion is the center of the aggregate. Such a concept is valid for oxygen and other halogens as the coordination centers bridging various metals, but is still undisclosed for halogen atoms. Only a limited number of coordination compounds with a halogen central atom were described, falling mainly to the groups of periodo tungstates or molybdates [29-31]. To the best of our knowledge, there are only three examples of coordination compounds where a low valent halogen atom is present in an aggregate bridging, thus more metal centers with minimum number of 'ligands' being six- $\left(\mathrm{Bi}_{10} \mathrm{I}_{20}\right)^{10+}$, $\left(\mathrm{Pb}_{10} \mathrm{I}_{20}\right)$ [32], and $\left(\mathrm{Pb}_{10} \mathrm{I}_{24}\right)^{4-}$ [33] - mostly on the basis of the topological analysis being considered as Archimedean polyhedra not Platonian solids. These facts and the unusual bonding behavior of the low valent arsenic fragments to the negatively charged iodine atom led us to the idea of a broader inspection of the nature of these interactions.

a)

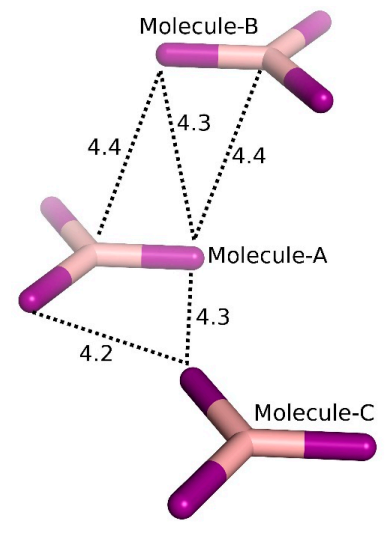

b)

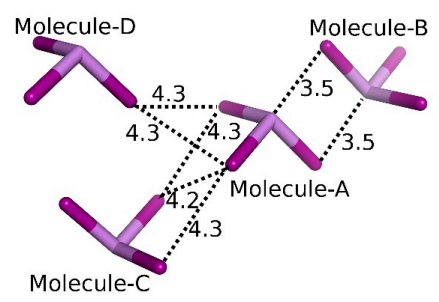

Figure 2. The interaction motifs of the studied crystals of $(\mathbf{a}) \mathrm{BI}_{3},(\mathbf{b}) \mathrm{AsI}_{3}$. Distances in $\AA$. 


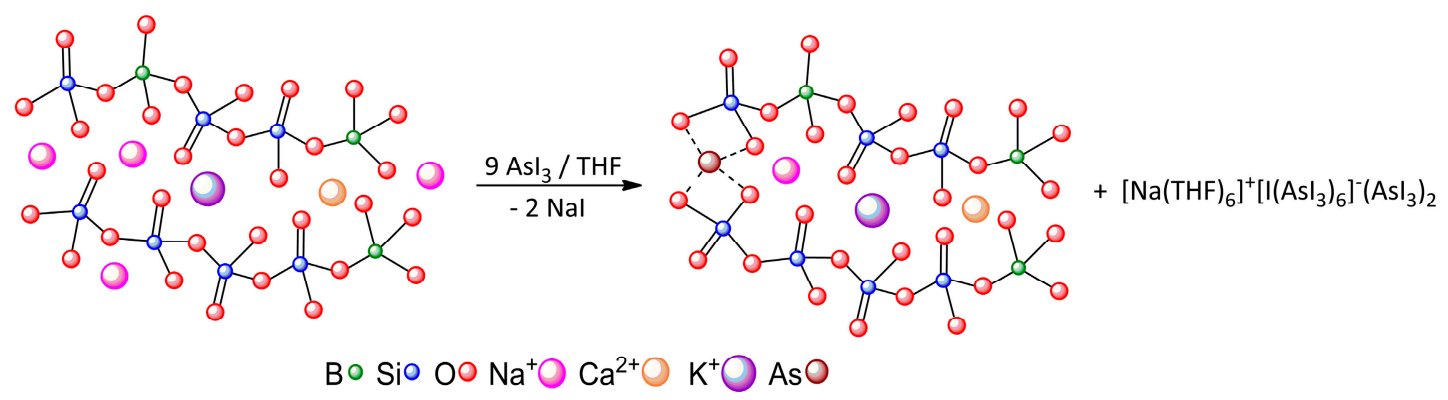

Figure 3. Schematic view of borosilicate glass $2 \mathrm{D}$ structure acting in the proposed reaction as a sodium atom source leading to the formation of $\left[\mathrm{Na}(\mathrm{THF})_{6}\right]^{+}\left[\mathrm{I}\left(\mathrm{AsI}_{3}\right)_{6}\right]^{-}\left(\mathrm{AsI}_{3}\right)_{2}$.

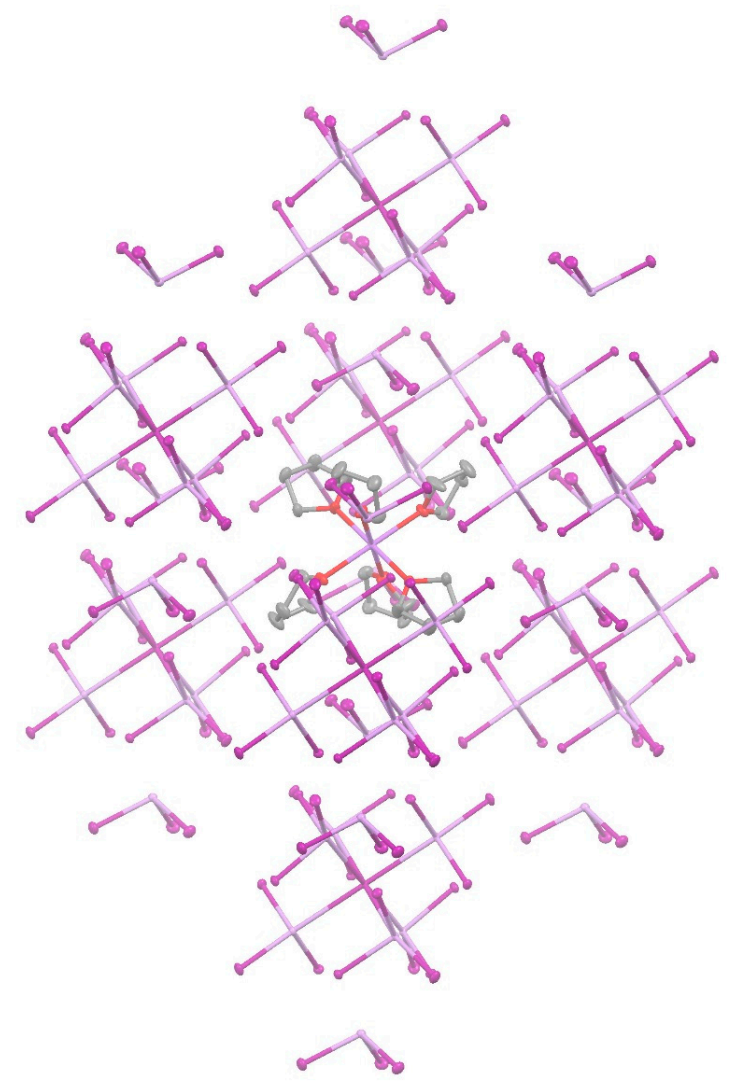

Figure 4. Crystal packing of the $\left[\mathrm{Na}(\mathrm{THF})_{6}\right]^{+}\left[\mathrm{I}\left(\mathrm{AsI}_{3}\right)_{6}\right]^{-}\left(\mathrm{AsI}_{3}\right)_{2}$.

When analyzing Pn- and diX-bonding in the $\left[\mathrm{Na}(\mathrm{THF})_{6}\right]^{+}\left[\mathrm{I}\left(\mathrm{AsI}_{3}\right)_{6}\right]^{-}\left(\mathrm{AsI}_{3}\right)_{2}$ complex (see Figure 5), we found very strong Pn-bonding to an iodine ion (the As $\cdots \mathrm{I}^{-}$distance of about $3.3 \AA$, the I-As $\cdots \mathrm{I}^{-}$angle of $162.6^{\circ}$, the $\Delta \mathrm{E}$ of $-23.59 \mathrm{kcal} \cdot \mathrm{mol}^{-1}$ ). Another Pn-bond can be found between two $\mathrm{AsI}_{3}$ molecules (the As $\cdots$ I distance of about $3.5 \AA$, the I-As $\cdots$ I angle of $168.9^{\circ}$, the As $\cdots$ I-As angle of $98.0^{\circ}$, the $\Delta \mathrm{E}$ of $-4.64 \mathrm{kcal} \cdot \mathrm{mol}^{-1}$ ). There is also interesting diX-bonding in the crystal structure

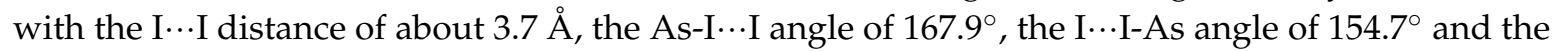
$\Delta \mathrm{E}-2.24 \mathrm{kcal} \cdot \mathrm{mol}^{-1}$. Based on the values of the I $\cdots \mathrm{I}$-As angle and the $\Delta \mathrm{E}$ of this diX-bonding in the B $\cdots C$ motif, this interaction might seem weak and not very important. Evidently, the $\sigma$-hole interactions of $\mathrm{AsI}_{3}$ units contribute significantly to the stability of the crystal but interactions of higher units could be important as well. Therefore, we also investigated interactions between the larger $\left(\mathrm{AsI}_{3}\right)_{6} \mathrm{I}^{-}$units. The resulting $\Delta \mathrm{E}$ is repulsive due to the electrostatic repulsion between $\mathrm{I}^{-}$ions. In the real crystal, this electrostatic repulsion is screened by counter ions and, therefore, we computed the interaction energy for the neutral $\left(\mathrm{AsI}_{3}\right)_{6}$ dimer not containing the I anions. Since the $\left(\mathrm{AsI}_{3}\right)_{6}$ 
dimer would be an excessively large molecule for the demanding $\operatorname{CCSD}(\mathrm{T})$ calculations, we have tested various DFT-D3 methods on the small $\mathrm{AsI}_{3}$ dimer. The best agreement between CCSD(T)/CBS and DFT-D3 values was found for the DFT-D3/BLYP/def2-QZVP level [34] (the $\Delta \mathrm{E}$ of -2.24 and $-2.27 \mathrm{kcal} \cdot \mathrm{mol}^{-1}$, respectively). The DFT-D3/BLYP/def2-QZVP method was then applied for the $\left(\mathrm{AsI}_{3}\right)_{6}$ dimer. The resulting stabilization energy of $8.46 \mathrm{kcal} \cdot \mathrm{mol}^{-1}$ is very large and clearly exceeds the energy of the Pn-bonding in the single A $\cdots B$ crystal motif. Interestingly, the dominant part $\left(-11.5 \mathrm{kcal} \cdot \mathrm{mol}^{-1}\right)$ of the overall stabilization originates in the dispersion energy which again stresses the important stabilization role of this systematically attractive contribution.

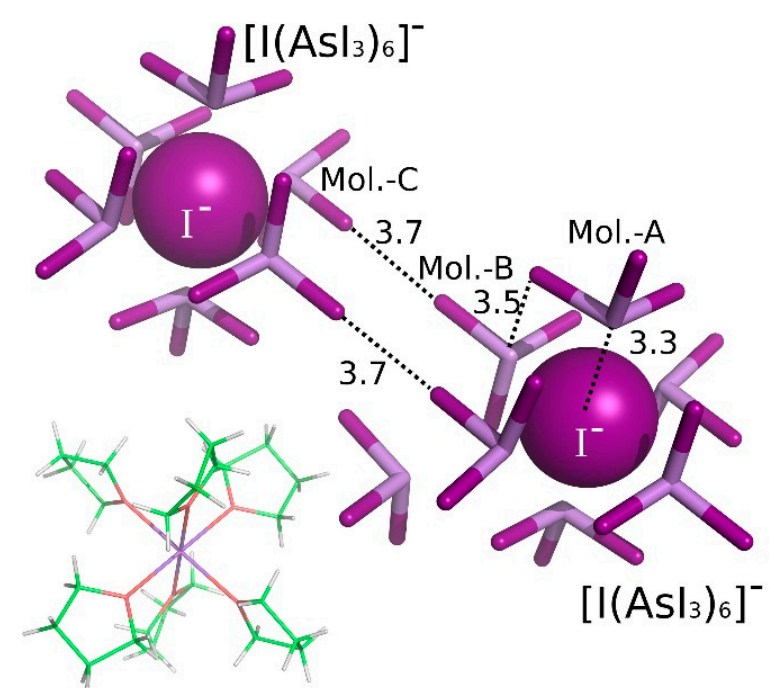

Figure 5. The studied interaction motifs of the $\left[\mathrm{Na}(\mathrm{THF})_{6}\right]^{+}\left[\mathrm{I}\left(\mathrm{AsI}_{3}\right)_{6}\right]^{-}\left(\mathrm{AsI}_{3}\right)_{2}$ crystal. Distances in $\AA$.

\section{Conclusions}

We have studied the interplay between $\sigma$ - and $\pi$-hole interactions in the known solid state structures of $\mathrm{BI}_{3}$ and $\mathrm{AsI}_{3}$ as well as in the newly reported $\left[\mathrm{Na}(\mathrm{THF})_{6}\right]^{+}\left[\mathrm{I}\left(\mathrm{AsI}_{3}\right)_{6}\right]^{-}\left(\mathrm{AsI}_{3}\right)_{2}$ complex. The last one can be described as the inverse coordination compound where the iodine anion is the center of the aggregate. The quantum chemical calculations have revealed that the crystal packing of $\mathrm{BI}_{3}$ is dominated by $\pi$-hole interactions. In the case of the $\mathrm{AsI}_{3}$ molecule, a more important role is played by diX-bonding, whose overall contribution is comparable to the Pn-bonding for the monocrystal packing of $\mathrm{AsI}_{3}$. Finally, we found a strong stabilization between two $\left[\mathrm{I}\left(\mathrm{AsI}_{3}\right)_{6}\right]^{-}$units where besides expected $\sigma$-hole interactions, systematically attractive dispersion interactions play a surprisingly important role.

Acknowledgments: This work was supported by the research project RVO 61388963 of the Czech Academy of Sciences. We acknowledge the financial support of the Czech Science Foundation (PH: P208/12/G016 and JF, DH, PŠ, AR and ZR: 17-08045S). This work was supported by the Ministry of Education, Youth and Sports from the Large Infrastructures for Research, Experimental Development, and Innovations project "IT4Innovations National Supercomputing Center-LM2015070" as well as from the project LO1305 (PH).

Author Contributions: A.R. and Z.R. designed the experiments, P.Š. performed the experiments, A.R. and Z.R. analyzed the experimental data, D.H. and J.F. performed the calculations, and A.R., D.H., J.F. and P.H. wrote the paper.

Conflicts of Interest: The authors declare no conflict of interest.

\section{References}

1. Clark, T.; Hennemann, M.; Murray, J.S.; Politzer, P. Halogen Bonding: The $\sigma$-Hole. J. Mol. Model. 2007, 13, 291-296. [CrossRef] [PubMed]

2. Wang, H.; Wang, W.; Jin, W.J. $\sigma$-Hole Bond vs $\pi$-Hole Bond: A Comparison Based on Halogen Bond. Chem. Rev. 2016, 116, 5072-5104. [CrossRef] [PubMed] 
3. Cavall, G.; Metrangolo, P.; Milani, R.; Pilati, T.; Primagi, A.; Ransani, G.; Terraneo, G. The Halogen Bond. Chem. Rev. 2016, 116, 2478-2601. [CrossRef] [PubMed]

4. Bundhun, A.; Ramasami, P.; Murray, J.S.; Politzer, P. Trends in $\sigma$-hole strengths and interactions of F3MX molecules ( $\mathrm{M}=\mathrm{C}$, Si, Ge and X = F, Cl, Br, I). J. Mol. Model. 2013, 19, 2739-2746. [CrossRef] [PubMed]

5. Kolár̆, M.; Hostaš, J.; Hobza, P. The strength and directionality of a halogen bond are co-determined by the magnitude and size of the $\sigma$-hole. Phys. Chem. Chem. Phys. 2014, 16, 23279-23280.

6. Riley, K.E.; Murray, J.S.; Fanfrlik, J.; Rezac, J.; Sola, R.J.; Concha, M.C.; Ramos, F.M.; Politzer, P. Halogen Bond Tunability I: The Effects of Aromatic Fluorine Substitution on the Strengths of Halogen-Bonding Interactions Involving Chlorine, Bromine, and Iodine. J. Mol. Model. 2011, 17, 3309-3318. [CrossRef] [PubMed]

7. Herdegger, L.A.; Kuhn, B.; Spinnler, B.; Anselm, L.; Ecabert, R.; Stihle, M.; Gsell, B.; Thoma, R.; Diez, J.; Benz, J.; et al. Systematic Investigation of Halogen Bonding in Protein-Ligand Interactions. Angew. Chem. Int. Ed. 2011, 50, 314-318. [CrossRef] [PubMed]

8. Fanfrlík, J.; Kolář, M.; Kamlar, M.; Hurny, D.; Ruiz, F.X.; Cousido-Siah, A.; Mitschler, A.; Řezáč, J.; Munusamy, E.; Lepšík, M.; et al. The Modulation of Aldose Reductase Inhibition by Halogen Bond Tuning. ACS Chem. Biol. 2013, 8, 2484-2492. [CrossRef] [PubMed]

9. Ring, M.A.; Donnay, J.D.H.; Koski, W.S. The Crystal Structure of Boron Triiodide. Inorg. Chem. 1962, 1, 109-111. [CrossRef]

10. Trotter, J. The crystal structure of arsenic triiodide, AsI 3 . Z. Kristallogr. Cryst. Mater. 1965, 121, 81-86. [CrossRef]

11. Sheldrick, G.M. Crystal structure refinement with SHELXL. Acta Crystallogr. Sect. C 2015, 71, 3-8. [CrossRef] [PubMed]

12. Bergner, M.; Dolg, M.; Küchle, W.; Stoll, H.; Preuss, H. Ab initio energy-adjusted pseudopotentials for elements of groups 13-17. Mol. Phys. 1993, 80, 1431-1441. [CrossRef]

13. Frisch, M.J.; Trucks, G.W.; Schlegel, H.B.; Scuseria, G.E.; Robb, M.A.; Cheeseman, J.R.; Scalmani, G.; Barone, V.; Mennucci, B.; Petersson, G.A.; et al. Gaussian 09, Revision, D.01; Gaussian, Inc.: Wallingford, CT, USA, 2009.

14. Flúkiger, P.; Lúthi, H.P.; Portmann, S.; Weber, J. MOLEKEL 4.3; Swiss Center for Scientific Computing: Manno, Switzerland, 2000.

15. Portmann, S.; Luthi, H.P. MOLEKEL: An Interactive Molecular Graphic Tool. CHIMIA Int. J. Chem. 2000, 54, 766-770.

16. Riley, K.E.; Tran, K.-A.; Lane, P.; Murray, J.S.; Politzer, P. Comparative analysis of electrostatic potential maxima and minima on molecular surfaces, as determined by three methods and a variety of basis sets. J. Comput. Sci. 2016, 17, 273-284. [CrossRef]

17. Ahlrichs, R.; Bar, M.; Haser, M.; Horn, H.; Kolmel, C. Electronic Structure Calculations on Workstation Computers: The Program System Turbomole. Chem. Phys. Lett. 1989, 162, 165-169. [CrossRef]

18. ̌nezáč, J. Cuby: An integrative framework for computational chemistry. J. Comput. Chem. 2016, 37, $1230-1237$. [CrossRef] [PubMed]

19. Halkier, A.; Helgaker, T.; Jørgensen, P.; Klopper, W.; Koch, H.; Olsen, J.; Wilson, A.K. Basis-Set Convergence in Correlated Calculations on $\mathrm{Ne}, \mathrm{N}_{2}$, and $\mathrm{H}_{2} \mathrm{O}$. Chem. Phys. Lett. 1998, 286, 243-252. [CrossRef]

20. Foord, A.; Beagley, B.; Reader, W.; Steer, I.A. A gas-phase electron-diffraction study of trvinylborane. J. Mol. Struct. 1975, 24, 131-137. [CrossRef]

21. Cornu, D.; Miele, P.; Faure, R.; Bonnetot, B.; Mongeot, H.; Bouix, J. Conversion of B $\left(\mathrm{NHCH}_{3}\right)_{3}$ into boron nitride and polyborazine fibres and tubular BN structures derived therefrom. J. Mater. Chem. 1999, 9, 757-761. [CrossRef]

22. Lo, R.; Svec, P.; Ruzickova, Z.; Ruzicka, A.; Hobza, P. On the nature of the stabilisation of the E $\cdots \pi$ pnicogen bond in the $\mathrm{SbCl}_{3} \cdots$ toluene complex. Chem. Commun. 2016, 52, 3500-3503. [CrossRef] [PubMed]

23. Schmidbaur, H.; Schier, A. $\pi$-Complexation of Post-Transition Metals by Neutral Aromatic Hydrocarbons: The Road from Observations in the 19th Century to New Aspects of Supramolecular Chemistry. Organometallics 2008, 27, 2361-2395. [CrossRef]

24. Fanfrlík, J.; Sedlak, R.; Pecina, A.; Rulíšek, L.; Dostál, L.; Moncól', J.; Růžička, A.; Hobza, P. The non-planarity of the benzene molecule in the X-ray structure of the chelated bismuth(III) heteroboroxine complex is not supported by quantum mechanical calculations. J. Chem. Soc. Dalton Trans. 2016, 45, 462-465. [CrossRef] [PubMed] 
25. Grund, S.C.; Hanusch, K.; Wolf, H.U. Arsenic and Arsenic Compounds, Ullmann's Encyclopedia of Industrial Chemistry; Wiley-VCH: Weinheim, Germany, 2005.

26. Scholes, R.S. Arsenic in Glass. Ind. Eng. Chem. 1912, 4, 16-17. [CrossRef]

27. Delgado-Friedrichs, O.; Foster, M.D.; O'Keeffe, M.; Proserpio, D.M.; Treacy, M.M.J.; Yaghi, O.M. What do we know about three-periodic nets? J. Solid State Chem. 2005, 178, 2533-2554. [CrossRef]

28. Haiduc, I. Inverse coordination-An emerging new chemical concept. Oxygen and other chalcogens as coordination centers. Coord. Chem. Rev. 2017, 338, 1-26. [CrossRef]

29. Honda, D.; Ikegami, S.; Inoue, T.; Ozeki, T.; Yagasaki, A. Protonation and methylation of an Anderson-type polyoxoanion [ $\left.\mathrm{IMo}_{6} \mathrm{O}_{24}\right]^{5-}$. Inorg. Chem. 2007, 46, 1464-1470. [CrossRef] [PubMed]

30. Long, D.L.; Song, Y.F.; Wilson, E.F.; Kögerler, P.; Guo, S.X.; Bond, A.M.; Hargreaves, J.S.; Cronin, L. Capture of Periodate in a $\left\{\mathrm{W}_{18} \mathrm{O}_{54}\right\}$ Cluster Cage Yielding a Catalytically Active Polyoxometalate $\left[\mathrm{H}_{3} \mathrm{~W}_{18} \mathrm{O}_{56}\left(\mathrm{IO}_{6}\right)\right]^{6-}$ Embedded with High-Valent Iodine. Angew. Chem. Int. Ed. 2008, 47, 4384-4387. [CrossRef] [PubMed]

31. Wang, S.M.; Chen, W.L.; Wang, E.B.; Li, Y.G.; Feng, X.J.; Liu, L. Three new polyoxometalate-based hybrids prepared from choline chloride/urea deep eutectic mixture at room temperature. Inorg. Chem. Commun. 2010, 13, 972-975. [CrossRef]

32. Liu, Y.; Hu, C.; Comotti, A.; Ward, M.D. Supramolecular Archimedean cages assembled with 72 hydrogen bonds. Science 2011, 333, 436-440. [CrossRef] [PubMed]

33. Krautscheid, H.; Lode, C.; Vielsack, F.; Vollmer, H. Synthesis and crystal structures of iodoplumbate chains, ribbons and rods with new structural types. J. Chem. Soc. Dalton Trans. 2001, 7, 1099-1104. [CrossRef]

34. Grimme, S.; Antony, J.; Ehrlich, S.; Krieg, S. A consistent and accurate ab initio parametrization of density functional dispersion correction (dft-d) for the 94 elements H-Pu. J. Chem. Phys. 2010, 132, 154104. [CrossRef] [PubMed]

(C) 2017 by the authors. Licensee MDPI, Basel, Switzerland. This article is an open access article distributed under the terms and conditions of the Creative Commons Attribution (CC BY) license (http:/ / creativecommons.org/licenses/by/4.0/). 